\title{
Acute kidney injury after cardiac surgery: a preventable event?
}

\author{
Kenta Kubota $^{1} \cdot$ Moritoki Egi $^{1}\left[\right.$ ] Satoshi Mizobuchi ${ }^{1}$
}

Received: 6 June 2017 / Accepted: 6 July 2017 / Published online: 19 July 2017

(C) Japanese Society of Anesthesiologists 2017

Cardiovascular surgery (CVS) is one of the major causes of acute kidney injury (AKI). A recently published singlecenter retrospective study conducted in 767 adult critically ill patients, mainly cardiac and postoperative patients, showed that the incidence of AKI was high in this cohort $(51.9 \%)$ and that the mortality rate increased with progression of the AKI stage [1]. A similar high incidence of AKI and its association with poor outcomes have also been reported in post-CVS patients in several studies [2-5].

In the past decade, many studies have been carried out with the aim to identify a sensitive biomarker for the early diagnosis of AKI in patients who had undergone CVS. To date, several useful biomarkers have been reported, including urine neutrophil gelatinase-associated lipocalin (NGAL), kidney injury marker $1, N$-acetyl- $\beta$ D-glucosaminidase (NAG), cystatin $C$, liver-type fatty acid-binding protein (L-FABP) and interleukin-18 [6, 7]. Among these biomarkers, NGAL, NAG, cystatin $\mathrm{C}$ and L-FABP are covered by Japan's National Heath Insurance system. Early identification of AKI using such biomarkers may improve the outcome by widening the therapeutic time window in post-CVS patients. Thus, it is time to ask whether the development of AKI in patients who have undergone CVS is a preventable event or not.

Multiple pathophysiologies are considered to be involved in the development of AKI in patients post-CVS. Numerous risk factors have been reported, including advanced age, anemia, diabetes, chronic lung disease, chronic heart failure, chronic renal dysfunction, administration

Moritoki Egi

moriori@tg8.so-net.ne.jp

1 Department of Anesthesiology, Kobe University Hospital, 7-5-1 Kusunoki-cho, Chuo-ku, Kobe City 650-0017, Japan of nephrotoxic agents, hypoperfusion, embolization and increased aortic clamp time [8]. Some of the risk factors can be treated or avoided. For example, it may be crucial to avoid ischemic damage during renal hypoperfusion due to perioperative low cardiac output syndrome and cardiogenic shock [8, 9]. A systematic review by Brienza et al. showed that postoperative AKI was significantly reduced using perioperative hemodynamic optimization [10]. However, it is not easy to achieve perioperative hemodynamic optimization in CVS patients, especially in those with low output syndrome. In this context, recent studies have provided useful information for determining the optimal inotrope in CVS patients [11-13]. Levosimendan is a calcium sensitizer that binds to troponin- $\mathrm{C}$, thereby sensitizing the myocardial filaments to calcium. Although several metaanalyses of small trials have suggested that levosimendan improves the survival rates among patients undergoing cardiac surgery $[11,13,14]$, a recently published randomized controlled trial has shown that levosimendan does not reduce the incidence of AKI and other clinical outcomes, including 30-day mortality and duration of mechanical ventilation and hospital stay, respectively [15]. In this regard, the optimal inotrope to improve outcomes, including the prevention of AKI, remains unidentified.

Pharmacologic renal protection is another important issue in patients undergoing CVS. Various agents, including dopamine, fenoldopam, statins, sodium bicarbonate, mannitol, $\mathrm{N}$-acetylcysteine, atrial natriuretic peptide and free hemoglobin scavengers, have been proposed as agents providing pharmacologic renal protection [16-19]. However, the results of studies in which the impact of such pharmacologic renal protection was assessed have not been consistent.

Studies have been carried out recently to assess the risks and benefits of various interventions to prevent AKI in 
patients who have undergone CVS [16-19], but as yet no definitive strategy to prevent AKI has been identified. Considering the multiple pathophysiologies of AKI post-CVS, it is possible that the prevention of AKI in this context can not be achieved through a single intervention [20]. It may therefore be better to consider combination interventions in future trials.

\section{References}

1. Izawa J, Uchino S, Takinami M. A detailed evaluation of the new acute kidney injury criteria by KDIGO in critically ill patients. J Anesth. 2016;30:215-22.

2. Perry TE, Muehlschlegel JD, Liu KY, Fox AA, Collard CD, Shernan SK, Body SC, Investigators CG. Plasma neutrophil gelatinase-associated lipocalin and acute postoperative kidney injury in adult cardiac surgical patients. Anesth Analg. 2010;110:1541-7.

3. Ryden L, Sartipy U, Evans M, Holzmann MJ. Acute kidney injury after coronary artery bypass grafting and long-term risk of end-stage renal disease. Circulation. 2014;130:2005-11.

4. Rosner MH, Okusa MD. Acute kidney injury associated with cardiac surgery. Clin J Am Soc Nephrol. 2006;1:19-32.

5. Hobson CE, Yavas S, Segal MS, Schold JD, Tribble CG, Layon AJ, Bihorac A. Acute kidney injury is associated with increased long-term mortality after cardiothoracic surgery. Circulation. 2009; 119:2444-53.

6. Ho J, Tangri N, Komenda P, Kaushal A, Sood M, Brar R, Gill K, Walker S, MacDonald K, Hiebert BM, Arora RC, Rigatto C. Urinary, plasma, and serum biomarkers' utility for predicting acute kidney injury associated with cardiac surgery in adults: a metaanalysis. Am J Kidney Dis. 2015;66:993-1005.

7. Obata Y, Kamijo-Ikemori A, Ichikawa D, Sugaya T, Kimura K, Shibagaki Y, Tateda T. Clinical usefulness of urinary liver-type fatty-acid-binding protein as a perioperative marker of acute kidney injury in patients undergoing endovascular or open-abdominal aortic aneurysm repair. J Anesth. 2016;30:89-99.

8. Mariscalco G, Lorusso R, Dominici C, Renzulli A, Sala A. Acute kidney injury: a relevant complication after cardiac surgery. Ann Thorac Surg. 2011;92:1539-47.

9. Egi M, Bellomo R, Langenberg C, Haase M, Haase A, Doolan L, Matalanis G, Seevenayagam S, Buxton B. Selecting a vasopressor drug for vasoplegic shock after adult cardiac surgery: a systematic literature review. Ann Thorac Surg. 2007;83:715-23.

10. Brienza N, Giglio MT, Marucci M, Fiore T. Does perioperative hemodynamic optimization protect renal function in surgical patients? A meta-analytic study. Crit Care Med. 2009;37:2079-90.

11. Zhou C, Gong J, Chen D, Wang W, Liu M, Liu B. Levosimendan for prevention of acute kidney injury after cardiac surgery: a meta-analysis of randomized controlled trials. Am J Kidney Dis. 2016;67:408-16.

12. Shang G, Yang $X$, Song D, Ti Y, Shang Y, Wang Z, Tang M, Zhang Y, Zhang W, Zhong M. Effects of levosimendan on patients with heart failure complicating acute coronary syndrome: a meta-analysis of randomized controlled trials. Am J Cardiovasc Drugs. 2017. doi: 10.1007/s40256-017-0237-0

13. Lim JY, Deo SV, Rababa'h A, Altarabsheh SE, Cho YH, Hang D, McGraw M, Avery EG, Markowitz AH, Park SJ. Levosimendan reduces mortality in adults with left ventricular dysfunction undergoing cardiac surgery: a systematic review and metaanalysis. J Card Surg. 2015;30:547-54.

14. Ushio M, Egi M, Wakabayashi J, Nishimura T, Miyatake Y, Obata N, Mizobuchi S. Impact of milrinone administration in adult cardiac surgery patients: updated meta-analysis. J Cardiothorac Vasc Anesth. 2016;30:1454-60.

15. Landoni G, Lomivorotov VV, Alvaro G, Lobreglio R, Pisano A, Guarracino F, Calabro MG, Grigoryev EV, Likhvantsev VV, Salgado-Filho MF, Bianchi A, Pasyuga VV, Baiocchi M, Pappalardo F, Monaco F, Boboshko VA, Abubakirov MN, Amantea B, Lembo R, Brazzi L, Verniero L, Bertini P, Scandroglio AM, Bove T, Belletti A, Michienzi MG, Shukevich DL, Zabelina TS, Bellomo R, Zangrillo A, Group CS. Levosimendan for hemodynamic support after cardiac surgery. N Engl J Med. 2017;376:2021-31.

16. Patel NN, Rogers CA, Angelini GD, Murphy GJ. Pharmacological therapies for the prevention of acute kidney injury following cardiac surgery: a systematic review. Heart Fail Rev. 2011;16:553-67.

17. Shin SR, Kim WH, Kim DJ, Shin IW, Sohn JT. Prediction and prevention of acute kidney injury after cardiac surgery. Biomed Res Int. 2016;2016:2985148.

18. Kubota K, Egi M, Mizobuchi S. Haptoglobin administration in cardiovascular surgery patients: its association with the risk of postoperative acute kidney injury. Anesth Analg. 2017; 124:1771-6.

19. Moriyama T, Hagihara S, Shiramomo T, Nagaoka M, Iwakawa S, Kanmura Y. The protective effect of human atrial natriuretic peptide on renal damage during cardiac surgery. J Anesth. 2017;31:163-9.

20. Ortega-Loubon C, Fernandez-Molina M, Carrascal-Hinojal Y, Fulquet-Carreras E. Cardiac surgery-associated acute kidney injury. Ann Card Anaesth. 2016;19:687-98. 